\title{
Brand orientation: a systematic literature review and research agenda
}

\section{Orientación de marca: una revisión sistemática de la literatura y agenda de investigación}

\author{
Lara Mendes Christ Bonella Sepulcri and \\ Emerson Wagner Mainardes \\ Department of Management, FUCAPE Business School, Vitória, Brazil, and \\ Danilo Magno Marchiori \\ Department of Management, University of Beira Interior, Covilhã, Portugal and \\ Department of Management, Mackenzie Presbyterian University, São Paulo, Brazil
}

\begin{abstract}
Purpose - Various studies dealing with brand orientation were analysed to discuss how the issues identified in this area have been relating over time. This paper aims to identify the key studies, the keywords used and the origin of the studies.
\end{abstract}

Design/methodology/approach - A systematic literature review (SLR) was performed within the Scopus database to select and summarize the studies that deal with brand orientation. Finally, 90 articles were subjected to bibliometric analysis.

Findings - Five major research areas were identified (brand orientation concept, hybrid strategies, internal branding management, brand performance and perceived brand orientation) and discussed.

(C) Lara Mendes Christ Bonella Sepulcri, Emerson Wagner Mainardes and Danilo Magno Marchiori. Published in Spanish Journal of Marketing - ESIC. Published by Emerald Publishing Limited. This article is published under the Creative Commons Attribution (CC BY 4.0) licence. Anyone may reproduce, distribute, translate and create derivative works of this article (for both commercial and non-commercial purposes), subject to full attribution to the original publication and authors. The full terms of this licence may be seen at http://creativecommons.org/licences/by/4.0/legalcode

This research was supported by Brazilian National Council for Scientific and Technological Development (CNPq/Brazil), project 304209/2018-0, by Foundation for Research Support of Espírito Santo (FAPES/Brazil), projects 81870973 (50/2018), 84513772 (599/2018) and 85395650 (228/2019), by Portuguese Science Foundation (FCT/Portugal) through NECE (Núcleo de Estudos em Ciências Empresariais), project UID/GES/04630/2019, and by IFTS (Instituto Fucape de Tecnologias Sociais), project 2018-2021. orientation

Received 19 June 2019 Accepted 17 December 2019

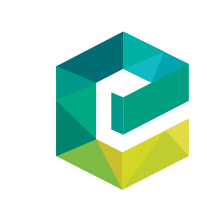

Spanish Journal of Marketing Vol. 24 No.1, 2020 pp. $97-113$ Emerald Publishing Limited DOI 10.1108/SJME-06-2019-0035 
Research limitations/implications - As the main theoretical contribution, the results showed a focus on research in five areas: the development of the brand orientation concept and proposed extensions; hybrid strategies; the relations between brand orientation, internal branding and brand management; the relation between brand orientation and financial performance; and the perceived brand orientation, mostly applied to higher education sector.

Originality/value - The study offers a general overview of brand orientation, identifying relations on topics of interest, main keywords and sub-themes in this field. The results contribute to fulfilling the research gap about the relationship between all these aspects. Finally, an agenda for future research is proposed.

Keywords Brand, Bibliometric analysis, Brand orientation, Systematic literature review

Paper type General review

\section{Resumen}

Propósito - Se analizaron diversos estudios sobre la orientación de la marca con el fin de discutir cómo se han ido relacionando a lo largo del tiempo los problemas identificados en esta área. Esta investigación identifica los estudios clave, las palabras clave utilizadas y el origen de los estudios.

Metodología - Se realizó una revisión sistemática de la literatura (SLR) con la base de datos de Scopus para seleccionar y resumir los estudios que tratan de la orientación de la marca. Finalmente, 90 artículos fueron sometidos al análisis bibliométrico.

Hallazgos - Se identificaron cinco grandes áreas de investigación (concepto de orientación de marca, Estrategias híbridas, Gestión interna de marca, Rendimiento de marca, Orientación de marca percibida) y se discutieron.

Implicaciones de la investigación - Los resultados mostraron un enfoque en la investigación en cinco áreas: el desarrollo del concepto de orientación de marca y las extensiones propuestas; las estrategias híbridas; las relaciones entre la orientación de marca, el branding interno y la gestión de marca; la relación entre la orientación de marca y el rendimiento financiero; y la orientación de marca percibida, aplicada principalmente al sector de la educación superior.

Originalidad/valor - El estudio ofrece una visión general de la orientación de la marca, identificando las relaciones sobre temas de interés, las principales palabras clave y los subtemas en este campo. Los resultados contribuyen a llenar el vacío de investigación sobre la relación entre todos estos aspectos. Finalmente, se propone una agenda futura de investigación.

Palabras clave Orientación de marca, Marca, Análisis bibliométrico, Revisión sistemática de la literatura Tipo de artículo Revisión general

\section{Introduction}

The representativeness of a brand and its relevance can be, along with other aspects, translated into consumer loyalty and consumer willingness to pay a premium price, so that the strengthening of the brand can revert to financial performance gains (Fischer et al., 2010; Simon and Sullivan, 1993). Thus, in the twentieth century, a new organizational strategy of brand orientation was theorized, taking the focus of the company from just meeting the needs of customers to creating a strategic meaning for the brand (Urde, 1999). Since then, studies in this area have evolved from the discussion about brand orientation to the analysis of its importance in companies (Anees-ur-Rehman et al., 2016).

For Urde (1994, 1999), a brand-oriented company focuses on creating, developing and protecting brand identity, represented as the essence of the firm's strategy. Since the inception of this concept, different studies have analysed the same concept in diverse contexts (Cant et al., 2013; Gromark and Melin, 2013; Jain et al., 2018; King et al., 2013; Napoli, 2006). In addition to empirical implications, several models were proposed to measure brand orientation, and its barriers, antecedents and outcomes (Apaydin, 2011; Boso et al., 2016; Harrison-Walker, 2014b; Huang and Tsai, 2013). 
Therefore, given the diversity of empirical and theoretical production over 20 years, we understand that it is necessary not only to systematize the content produced but also to further understand the relationship between the published research and the main thematic areas. For this purpose, our study aimed to analyse the studies that deal with brand orientation, to:

- identify the origin of the research (i.e. which institutions and which countries explore more the studies in this area);

- identify the key studies and keywords used; and

- discuss how the identified issues addressed in this area have been relating over time.

Despite the existence of a systematic literature review on the theme (Anees-ur-Rehman et al., 2016), we noticed that this study did not use bibliometric analyses, to deepen the understanding of the themes analysed. The use of statistical and mathematical techniques allows researchers to expand their vision about the object of study due to the identification of bibliometric relations on the topics of interest: main keywords and their relations; the relationship between sub-themes; and the main authors in the area (Börner et al., 2003; Waltman et al., 2010). Thus, the use of statistical techniques, through a bibliometric analysis, enabled us to see some relationships that cannot be seen from a simple content analysis, filling the research gap about the relationship between brand orientation, its extensions proposed by Anees-ur-Rehman et al. (2016), the sectors and the contexts explored by the studies.

To respond to the objective of the study, we performed a systematic literature review to generate a database to analyse bibliometricaly and better interpret the results. Thus, the bibliographic analysis techniques were applied to a final sample of 90 articles published between 1994 and 2018 in the Scopus database. According to this analysis, the studies concentrate on themes and countries, generating good research opportunities by expanding the areas studied and the issues involved.

\section{Brand orientation}

Brand orientation can be regarded as a strategic approach, in which the brand becomes the centre around which the organization's processes are created through interactions of stakeholders. This closely ties it to business development and financial performance (Gromark and Melin, 2011), as highlighted in the studies by Anees-ur-Rehman et al. (2018) and Wong and Merrilees (2008). The theoretical development of this concept has been increasing since the year 2000, expanding to different extension, as suggested by Anees-urRehman et al. (2016).

Ewing and Napoli (2005) developed a scale to verify the application of nonprofit brand orientation, whereas Apaydin (2011) suggested a theoretical model of antecedents and consequents to the orientations of brands in that area. Besides that, Liu et al. (2017) found a positive relationship between brand orientation and internal brand mechanisms, which corroborates with the idea that a brand orientation approach contributes to employees who have a better understanding of their role within a nonprofit company.

Furthermore, in the third sector, Mulyanegara (2011a) examined the brand orientation from the consumer perspective (Casidy, 2013), coining the concept "perceived brand orientation" (PBO) (Anees-ur-Rehman et al., 2016). In his study, Mulyanegara (2011a) concludes that active participation in churches is influenced by the positive evaluation of brand orientation as well as by the spiritual and social benefits derived from church programmes. Casidy (2013) analyses the PBO relationship with satisfaction, loyalty and post-enrollment behaviour in the higher education sector, indicating a significant relation with all the dependent variables. In the same way, Shahijan et al. (2016) also finds a positive relationship between perceived brand orientation and course satisfaction among international students in Malaysia. 
In the political field, the political brand orientation consists of how party brand values and party practices are in conformity. That is, how much they are oriented towards developing brand potentials (O'Cass and Voola, 2011). Downer (2016) works this concept to show how the actions of the party and its leaders can add or remove brand value, altering the value perceived by the voter.

In the same way, it is possible to develop the brand of a tourist destination and study it from this perspective. However, the tourist destination brand is an association of deliveries of products and services generated by distinct and often independent organizations (Hankinson, 2012). Therefore, destination brand orientation (DBO) proved to have a strongly positive relationship with brand performance (García et al., 2018; Hankinson, 2012).

Particularly in the service sector, employees play a key role in the quality of service delivered (King et al., 2013; Terglav et al., 2016). Thus, more specifically in the hotel industry, Terglav et al. (2016) indicate that the commitment employees have with the brand is related to the perception of the alignment between the behaviour of the brand managers. In the same line, King et al. (2013) highlight that there is a positive relationship between service brand orientation (SBO), employee orientation to the client and brand oriented behaviour.

When it comes to retail, the retail brand orientation (RBO) is described by Brïdson et al. (2013) as a strategy in which the organization prioritizes and manages the brand's distinctive, functional, augmented and symbolic attributes. Retailers who aim for a vantage point relative to competitors should invest in building a strong RBO. However, due to retail diversity, Schmidt et al. (2017) highlight that metrics may vary when analysed RBO in different retail sectors. Also, Balmer (2013) presented a concept of corporate brand orientation, where the corporate brand becomes the central pillar of the organization, reflecting the corporation's values, culture and identity. Thus, employees, customers and other stakeholders are protagonists to build the corporate brand, which may create an emotional engagement with it (Balmer, 2013).

In addition to the proposed extensions, brand orientation may also be linked to other strategies, generating the so-called hybrid strategies such as brand-market orientation and market-brand orientation, suggested by Urde et al. (2013). Thus, Laukkanen et al. (2016) point out that the market orientation strategy has a positive impact on the financial performance of small companies if it is implemented through the brand orientation, which also proved to be a mediating factor between entrepreneurial orientation and business growth for small business-to-business (B2B) operating in emerging markets (Reijonen et al., 2015). This symbiosis is also present in political marketing, in which the parties that have the competencies to understand voters (political market orientation) and connect them with its offers (political brand orientation) would provide a unique value proposition, generating a clear differentiation from its rivals (O'Cass and Voola, 2011).

In spite of the various studies of brand orientation, both empirical and theoretical, it was noticed that a bibliometric analysis can contribute to a better understanding of the relations between studies about the subject. This type of analysis has, as one of the purposes, to use statistical and mathematical techniques to structure the information, generating clusters and maps, so that the relationships between the data can be enhanced and visualized in a way that facilitates interpretation (Börner et al., 2003; Pritchard, 1969; Waltman et al., 2010).

\section{Methods}

In the present study, we used two methodological approaches. Firstly, we conducted a systematic literature review based on Scopus, one of the largest peer-review scientific literature of large databases of scientific journals, also considered a consistent database to perform bibliometric analysis (Anees-ur-Rehman et al., 2016; Wang and Waltman, 2016). Moreover, Scopus uses rigorous criteria to index a journal, and all indexed journals are 
submitted to periodic evaluations to certify the maintenance of quality (Elsevier, 2019). This review was carried out to generate the database for conducting a bibliometric analysis in which we used the techniques of bibliographic coupling (Kessler, 1963) and analysis of co-occurrence of keywords (Callon et al., 1983).

\subsection{Systematic literature review}

The articles analysed in this study were identified through consultation with the scientific journals indexed to Scopus and Web of Science, with no category or date filters having been made, but rather language filters (only in English) and type of work (Articles and Reviews) instead. The terms used in the search engine were "brand orientation", "brand-orientation", "brand oriented" and "brand-oriented", combined with the Boolean operator OR. The search was applied in the article title fields, abstracts, and keywords. We conducted it in June 2018.

We made the initial research in both databases (Scopus and Web of Science). We found, after the initial scan, that 131 articles from Scopus and 72 articles from Web of Science met the inclusions criteria. From these articles, 57 were in both databases, 74 only in Scopus and 15 only in Web of Science. Thus, 131 articles were analysed, and of these, we excluded studies that:

- did not have any technical information like author, year or abstract;

- were not related to the areas of business, marketing, psychology or behaviour;

- used the customer's brand orientation as variable instead of brand orientation as strategy; and

- did not use brand orientation as a model variable, that is, they used brand orientation only as a theory to support the article, but did not evaluate it to meet the search goal.

This analysis was carried out by reading the titles, abstracts and introductions of the studies. Those that fit into at least one of the exclusion criteria were removed from the sample. In cases where there were still doubts whether to keep or exclude, we read the full article. Thus, the final sample consisted of 96 papers. In total, 45 were in both databases, 45 only in Scopus and 6 only in Web of Science. Finally, we synthesized the articles and, as Scopus presented a large number of articles, we chose this database to perform the bibliometric analysis.

\subsection{Bibliometrics}

To perform the bibliometric analysis, we used the VOSViewer software, version 1.6.10 (Van Eck and Waltman, 2010; Waltman et al., 2010). From this tool, we applied technique of bibliographic coupling (Kessler, 1963) and keyword co-occurrence analysis (Callon et al., 1983). In bibliographic coupling, the more references the articles share, the greater the similarity between them (Egghe and Rousseau, 2002; Kessler, 1963). Therefore, we suggest that each cluster formed by bibliographic coupling forms the basis of a determined research front, as that cluster has articles with common references (Jarneving, 2005).

As for the co-occurrence of keywords, the terms are grouped according to their degree of association in the literature, to identify which subjects were treated during the time. Thus, to examine the co-occurrence of keywords, it is analysed the frequency with which they appeared in the sample and how often two distinct keywords appear together in different jobs (Cobo et al., 2011; Losiewicz et al., 2000).

The interactions formed from the application of these techniques were exposed in network maps (Li et al., 2016; Marchiori and Mendes, 2018), being that, each map is calculated by measuring the force of interaction between terms, which takes into account the number of links between the terms (Van Eck and Waltman, 2010; Waltman et al., 2010). Graphically, the terms 
SJME

24,1

\section{2}

(which, in this case, are articles or keywords) are represented by nodes and colour clusters, so that larger nodes represent more relevant terms than smaller nodes. The lines indicate the links between the nodes, as well as the distance, so that the closer one node is to the other, the more related they are Cobo et al. (2011), Sinkovics (2016) and Van Eck and Waltman (2019).

\section{Results of bibliometric analysis}

\subsection{Main studies and institutions}

When analysing the most relevant studies in the area, we noted that the study by Wirtz et al. (2013) is the most cited among the articles in the sample, even though it is relatively recent, while Urde (1994), which starts the concept of brand orientation, appears as the fourth most cited. Table I shows the ten papers with the highest number of citations, the journals in which they were published, the number of citations, the total citations (TC) per year and their respective countries.

Among the institutions that have two or more publications in this area, most of them are from Australia and Europe. This happens not only in the production but also in the places where the research samples were collected, as shown by Anees-ur-Rehman et al. (2016).

\subsection{Co-occurrence keywords}

When applying the co-occurrence technique with all keywords and with fractional counting (Van Eck and Waltman, 2014), we found 236 different words. Of those, only those that had at least two occurrences were selected, generating 46 items. The keyword "brand orientation" was excluded from the analysis, as it was by this keyword that the articles were initially selected in the search engine. We also did an adjustment for keywords considered synonymous like "b2b" and "business-to-business". Five groups were found.

Group 1 comprised terms such as brand commitment, internal brand management and employees, possibly relating the effects of the work of internal brand on employee commitment to the brand, with the hospitality sector standing out in this group, as the examples of studies by King and So (2015) and King et al. (2013). Group 2 suggests papers that have explored small and medium-sized enterprises (SME's) with the type of business-to-

\begin{tabular}{|c|c|c|c|c|}
\hline Author & Journal & $\begin{array}{l}\text { No. of } \\
\text { citations }\end{array}$ & $\mathrm{TC}$ per year & Country \\
\hline Wirtz et al. (2013) & Journal of Service Management & 177 & 28.83 & UK \\
\hline $\begin{array}{l}\text { Wong and Merrilees } \\
\text { (2005) }\end{array}$ & Journal of Product and Brand Management & 126 & 8.93 & UK \\
\hline $\begin{array}{l}\text { Simões and Dibb } \\
\text { (2001) }\end{array}$ & $\begin{array}{l}\text { Corporate Communications: An International } \\
\text { Journal }\end{array}$ & 118 & 6.50 & UK \\
\hline Urde (1994) & Journal of Consumer Marketing & 107 & 4.24 & UK \\
\hline Urde et al. (2013) & Journal of Business Research & 106 & 17.50 & Holland \\
\hline Baumgarth (2010) & European Journal of Marketing & 100 & 11.11 & UK \\
\hline $\begin{array}{l}\text { Wong and Merrilees } \\
\text { (2008) }\end{array}$ & Journal of Product and Brand Management & 100 & 9.09 & UK \\
\hline Reid et al. (2005) & Journal of Advertising & 92 & 6.57 & USA \\
\hline $\begin{array}{l}\text { Ewing and Napoli } \\
\text { (2005) }\end{array}$ & Journal of Business Research & 88 & 6.21 & Holland \\
\hline $\begin{array}{l}\text { Brïdson and Evans } \\
\text { (2004) }\end{array}$ & $\begin{array}{l}\text { International Journal of Retail and Distribution } \\
\text { Management }\end{array}$ & 81 & 5.40 & UK \\
\hline
\end{tabular}

Table I. 
business consumer, directing the studies to the impacts of the brand orientation, as well as the adoption of hybrid strategies, financial performance and business growth. We noticed that, although market orientation does not belong to the same group, the term is very close to Group 2, mainly to b2b branding and strategic hybrid orientation, which indicates a strong relationship.

Group 3 is directed to the internal branding and market orientation, given that these two are the ones of greater relevance in the group. Similarly, both terms appear to be related to the nonprofit sector, internal marketing and perceived benefits generated, for example, by the association of the brand orientation with market orientation (Mulyanegara, 2011a). Also, Group 3 gathers keywords such as brand strategy, internal branding and brand equity that can be related to the positive impacts of brand orientation on internal branding and brand equity, as argued by Baumgarth and Schmidt (2010).

Group 4 indicates articles that seem to relate aspects of the brand such as management and identity and shows how these aspects relate to strategic orientation, given that the terms brand management, brand identity and strategic orientation are in this group. It is important to note that, besides the keywords "financial performance" and "brand performance" which do not belong to Group 4, the proximity shows a relationship between those subjects. Finally, Group 5 includes keywords like innovation, customer loyalty and customer satisfaction suggesting that these aspects may be related to brand orientation (Wong and Merrilees, 2008) with emphasis on the higher education sector (Casidy, 2014a, 2014b).

We observed that despite the concept of corporate brand orientation is one of the extensions of brand orientation (Anees-ur-Rehman et al., 2016; Balmer, 2013) this keyword (corporate brand orientation) is not widely used in the articles. On the other hand, corporate brand and corporate branding are the terms most frequently used (Powell, 2016) and appear in this study's sample.

\subsection{Bibliographic coupling}

To identify the interactions among the articles from the similarities between the references, we applied, in the sample, the technique of bibliographic coupling by documents, with fractional counting, which gives the same weight to each publication (Perianes-Rodriguez et al., 2016; Van Eck and Waltman, 2014). Thus, the map is shown in Figure 1, where each of the five clusters found was circled to facilitate visualization.

Therefore, when analysing the most cited studies within each cluster, the first cluster seems to gather studies that deal with conceptual discussions of brand orientation, bringing more theoretical studies, including the study by Urde (1994), who was one of the pioneers in the brand orientation theory. The most cited study of Cluster 2 empirically measures the effects of the adoption of hybrid strategies, like brand orientation with entrepreneurial orientation or brand orientation with market orientation, mainly in relation to growth and business performance. On the other hand, Cluster 3 presents, in its most cited studies, qualitative and quantitative articles, which relate to the development of the brand internally to the company or locally in a determined microregion. From another perspective, Cluster 4, despite its most cited articles, takes into account the impacts of a company to be brand oriented, usually in financial performance, and explores the concept of brand performance. Finally, the papers in Cluster 5 aim at the area of higher education, containing all the articles of the sample that cover this sector, and analysed the concept of perceived brand orientation. To summarize, Table II shows the four most cited studies, according to the Scopus, within each cluster and its main theme (Waltman et al., 2010). 


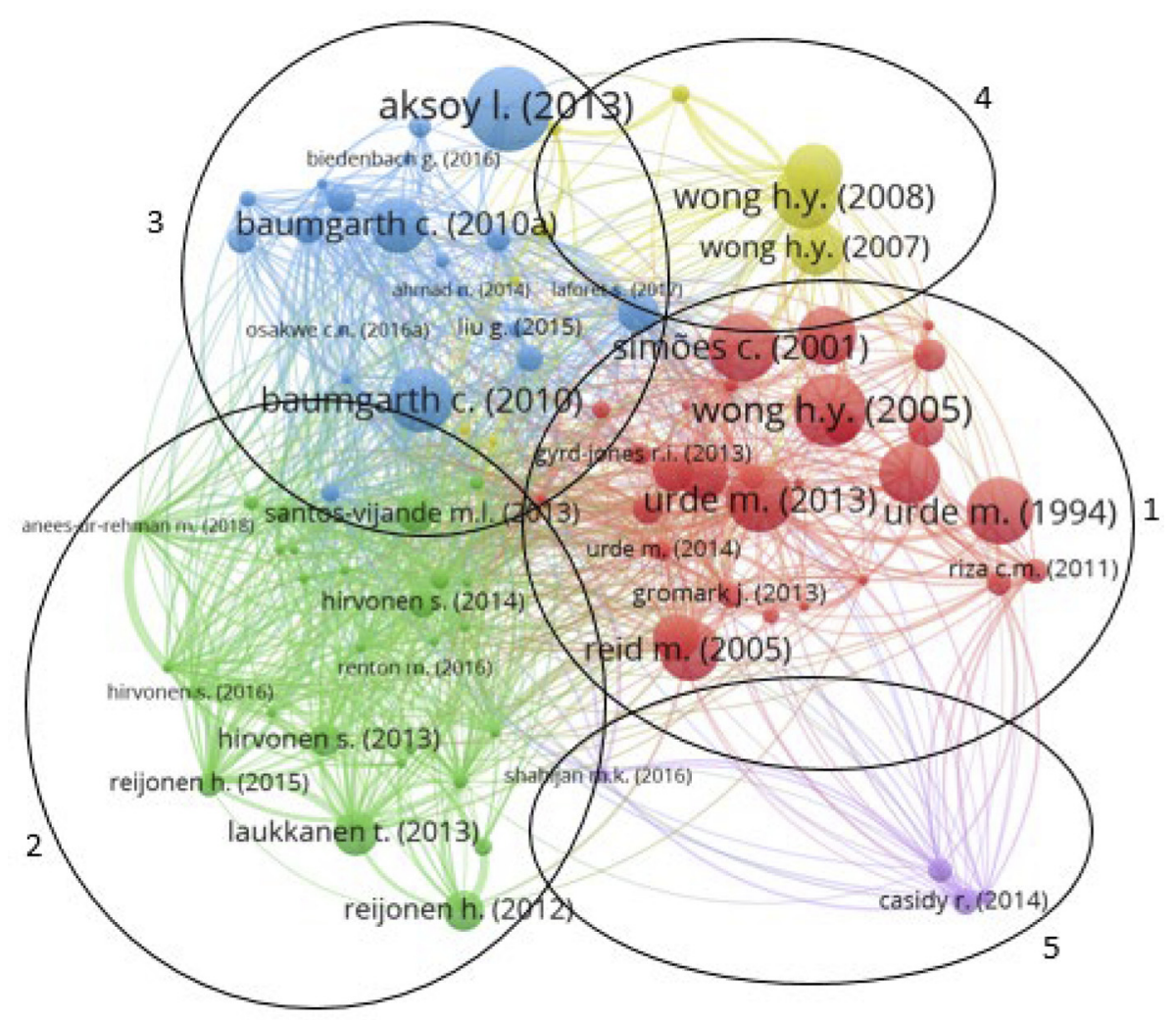

Figure 1.

$\mathrm{BC}$ documents
Note: The work of Wirtz et al. (2013) appears in Figure 1 as aksoy 1. (2013) by means of list of authors of the Scopus base

Source: Research data

\section{Cluster analysis and discussion of results}

In the bibliographic coupling, we can perceive the formation of five clusters: brand orientation concept hybrid strategies, internal branding management, brand performance and perceived brand orientation. When analysing each one of them it is possible to notice relations between some clusters and the keywords groups.

Cluster 1, titled brand orientation concept, set the base of brand orientation and strategic positioning theories, and it is formed by several qualitative studies. After Urde (1994) defines brand orientation, several studies developed scales to measure this concept, its antecedents, barriers and outcomes (Bridson and Evans, 2004; Gromark and Melin, 2011; Rentschler et al, 2011; Harrison-Walker, 2014a, 2014b). Besides, some researchers adapted the original concept to different areas such as nonprofits (Ewing and Napoli, 2005; Apaydin, 2011), retail (Bridson et al, 2013) and politics (O'Cass and Voola, 2011; Downer, 2016) and also to different perspectives as perceived brand orientation (Mulyanegara, 2011a, 2011b). Furthermore, papers that discuss hybrid strategies (Urde and Koch, 2014) and main positioning strategies (Urde et al., 2013) from a theoretical point also form this cluster. Thus, as this cluster is considered the 


\begin{tabular}{|c|c|c|c|c|}
\hline Author & Cit. & Main theme & Cluster & or: \\
\hline Wong and Merrilees (2005) & 126 & \multirow[t]{4}{*}{ Brand orientation concept } & \multirow[t]{4}{*}{1} & \\
\hline Simões and Dibb (2001) & 118 & & & \\
\hline Urde (1994) & 107 & & & \\
\hline Urde et al. (2013) & 106 & & & \\
\hline Laukkanen et al. (2013) & 51 & \multirow[t]{4}{*}{ Hybrid strategies } & \multirow[t]{4}{*}{2} & \\
\hline Reijonen et al. (2012) & 39 & & & 105 \\
\hline Santos-Vijande et al. (2013) & 37 & & & \\
\hline Hirvonen et al. (2013) & 25 & & & \\
\hline Wirtz et al. (2013) & 177 & \multirow[t]{4}{*}{ Internal brand management } & \multirow[t]{4}{*}{3} & \\
\hline Baumgarth (2010) & 100 & & & \\
\hline Baumgarth and Schmidt (2010) & 78 & & & \\
\hline Hankinson (2012) & 41 & & & \\
\hline Wong and Merrilees (2008) & 100 & \multirow{4}{*}{ Brand performance } & \multirow[t]{4}{*}{4} & \\
\hline Wong and Merrilees (2007b) & 81 & & & \\
\hline Wong and Merrilees (2007a) & 73 & & & \\
\hline Baxter et al. (2013) & 9 & & & \\
\hline Casidy (2014b) & 18 & \multirow[t]{5}{*}{ Perceived brand orientation } & \multirow[t]{5}{*}{5} & \\
\hline Casidy (2013) & 14 & & & \\
\hline Shahijan et al. (2016) & 6 & & & \\
\hline Casidy (2014a) & 5 & & & $\begin{array}{l}\text { Table II. } \\
\text { Bibliographic }\end{array}$ \\
\hline Source: Research data & & & & coupling clusters \\
\hline
\end{tabular}

base of brand orientation theory and their extensions, the keywords from the studies are spread in the different keywords' groups, which are analysed below. Also, as declared, the keyword brand orientation and its synonyms have been deleted from the keyword group analysis.

The hybrid strategies (Cluster 2) is formed by articles that are mostly empirical, using methodologies such as factor analysis, structural equation modelling, cluster analysis and regressions. Laukkanen et al. (2013) and Reijonen et al. (2015) suggest that different strategic orientations, in addition to brand orientation, may impact the relationship between entrepreneurial orientation and performance, encouraging the study of hybrid strategies. The adoption of another orientation strategy, also called a hybrid strategy, was still proposed by studies such as those by Anees-ur-Rehman et al. (2017), Lee et al. (2017) and Reijonen et al. (2012, 2014). There are also, in Cluster 2, several articles related to small and medium enterprises (Ciunova-Shuleska et al., 2016, 2017; Hirvonen and Laukkanen, 2014; Hirvonen et al., 2013, 2016) and the effects of adopting this positioning strategies in companies of this size (Chovancová et al., 2015; Laukkanen et al., 2013, 2016; Lee et al., 2016). Reijonen et al. (2012) suggest that small and medium growing companies are more brand and market oriented than other companies (stable or declining). This relation between hybrid strategies and small and medium companies can be seen in keyword groups, as the keywords "smes" and "entrepreneurial orientation" (Chovancová et al., 2015; Reijonen et al., 2015) belong to keyword Group 2. Also, although the keyword "market orientation" does not belong to Group 2, the proximity suggests a relation to the keyword Group 2.

Cluster 3 has, as its main theme, the internal branding management. Thus, the application of brand orientation strategy to the internal development of the brand is composed of articles that mostly use the factor analysis, structural equation modelling and multiple regressions. Research, such as Baumgarth and Schmidt (2010) and Zhang et al. (2016), explores the relationship between internal branding and brand equity. According to them, brand orientation has a positive impact on brand equity through internal branding. 
From another perspective, Wirtz et al. (2013), which was the most cited article in the cluster, propose a model that relates brand orientation and consumer engagement in online brand communities (OBCs), suggesting that the consumer engagement in OBC's can improve the brand equity. The relation between these themes can be seen through the keywords "internal branding", "brand strategy" and "brand equity" that appeared together in Group 3.

Also, some studies in Cluster 3 explore the relation between brand orientation and internal brand under an employee's commitment and behaviour, in both nonprofit and forprofit organizations (Dechawatanapaisal, 2018; King et al., 2013; Liu et al., 2015, 2017). In addition, strong internal brand development helps the employee to deliver services aligned with companies' promises (King and So, 2015). Thus, the relationship between the keywords on this theme, such as "brand commitment", "internal brand management and employees", is showed by Group 1.

The fourth cluster, titled brand performance, consists of both theoretical and empirical articles. Wong and Merrilees (2015) study the antecedents and consequents of brand engagement, showing that the brand orientation precedes this relationship and has positive consequences on brand performance and financial performance. Wong and Merrilees (2007a, 2008) have also studied the relationship between brand orientation and brand performance and the gap between brand performance and marketing strategy that, according to the authors, is partially filled by brand orientation. All articles were based in samples from Australia. Also, Varadarajan and Malone (2018) presented, through a case of study in a private international school in India, how branding improves the number of school enrollment. Gisip and Harun (2013) proposed a theoretical model where brand orientation is seen as a part of brand management strategy and has a positive relationship with brand performance.

Thus, the keywords in Group 4 gather together keywords such as "brand management, brand identity", "business performance" and "Australia", showing the association between the themes. Also, despite the keywords "financial performance" and "brand performance" (Group 2) belonging to a different keyword group, the proximity between these keywords suggests that these themes are related (Baxter et al., 2013; Wong and Merrilees, 2008).

Finally, the fifth cluster, titled perceived brand orientation, makes use of factor analysis and structural equation modeling and explores, for example, the positive relationships between brand orientation with student loyalty, satisfaction and intention to continue the course (Casidy, 2013, 2014a; Shahijan et al., 2016). As perceived brand orientation considers the customer's point of view, those studies using keywords as "customer satisfaction", "customer loyalty" or "student satisfaction" and "student loyalty" as those words are related with higher education. Keyword Group 5 shows these relationships.

In summary, articles show several relations between them. The internal aspects of the brand, and the adoption of hybrid strategies, mainly with market orientation, has been shown as a line of research that has aroused interest within the academic community, as well as the impacts of using these strategies on company performance. Still, perceived brand orientation seems to be a concept just being explored in a higher education and church context (Casidy, 2014a, 2014b; Mulyanegara, 2011a, 2011b), which reveals the opportunity to explore it in other sectors like in services, given the importance of consumer perception (Chovancová et al., 2015). Each cluster also show practical implications of adopting brand orientation such as gains in performance, the impact in growth associated with market orientation (Cluster 2), impacts on employees' commitment, employees behaviour and brand equity (Cluster 3), impacts on performance (Cluster 4) and impacts on customer satisfaction and loyalty (Cluster 5). 


\section{Research agenda}

The results show a latent need for diversification of research in different countries, mainly by comparing the causes and effects of the actions of brand orientation strategy in developed and developing economies (Laukkanen et al., 2013). In addition, some studies (Brïdson and Evans, 2004; Huang and Tsai, 2013; Osakwe et al., 2016) demonstrate that good brand orientation work is related to issues such as differentiation and engagement, characteristics that seem to be even more necessary in sectors such as nonprofit, services and online commerce. In this way, future research can explore the brand orientation in these sectors, considering, for example, if nonprofit companies that are more brand-oriented are more trustworthy, and are thus able to raise more donations or attract more volunteers.

In the field of online commerce, we can verify if the brand orientation impacts on the reliability of this type of retail, thus positively affecting the consumer's purchase intention. In the service sector, brand orientation can strengthen standardization, especially in companies that operate in different locations, with headquarters and subsidiaries, guaranteeing the same exclusive experience of the brand by the consumer, wherever they use the service (Boso et al., 2016). Wallace et al. (2013) suggest exploring brand orientation in hierarchical matrixes and branch structures, looking at the role of the local manager in the development of brand identity, and the influence of the local leader and his/her team.

Regarding the metrics used, the financial performance seems to be a very relevant metric and studied as a consequence of brand orientation (Anees-ur-Rehman et al., 2016). However, other aspects seem to be little explored, such as brand sustainability, innovation, productivity, loyalty and personality (Anees-ur-Rehman et al., 2017; Biedenbach and Manzhynski, 2016; Brïson and Evans, 2004; Gisip and Harun, 2013). The public sector is also little explored, with few studies in this context, even though Gromark and Melin (2013) point out brand orientation as an interesting alternative to market orientation in this sector.

Although some studies have explored the use of hybrid strategies in areas such as SMEs and $\mathrm{B} 2 \mathrm{~B}$, a few studies advance to the use of other strategies beyond marketing orientation, such as orientation for the technology, for the consumer, for innovation and entrepreneurship (Anees-ur-Rehman et al., 2018; Ciunova-Shuleska et al., 2017; M'zungu et al., 2017). It is also worth investigating when, how and what market positioning leads to the adoption of a certain strategy (Urde and Koch, 2014). And, the use of hybrid strategies in different contexts might be explored as a U-shape relationship instead of a linear relationship (Lee et al., 2016). Moreover, within the mix of characteristics that a certain segment can present, putting together, for example, small and medium-sized B2B and B2C companies from different countries with different strategies, the multi-group analysis can be a powerful tool to analyse these distinctions, as in the study by Reijonen et al. (2015). In addition, Boso et al. (2016) suggest research in the BRICS countries (Brazil, Russia, China, India and South Africa) and MINT (Mexico, Indonesia, Nigeria and Turkey) and studies that compare the results for both developed and developing economies (Powell, 2016).

Relating to internal branding, both external factors (such as market fluctuations, intensity of competition and technological changes) and internal factors (such as sustainability and innovation culture) can influence the development of the internal brand through brand orientation (Dechawatanapaisal, 2018; Huang and Tsai, 2013; Iyer et al., 2018). From another perspective, Wirtz et al. (2013) proposed a model that relates brand orientation and consumer engagement in OBCs. They suggested that future research could empirically test the differences between BCs (brand communities) online and offline, exploring when the firm should choose one or the other, as well as the antecedent and consequent model. The authors also suggest developing a scale to measure engagement in $\mathrm{OBCs}$ and test that engagement in brand performance. In addition, the authors suggest 
exploring the criteria to determine in which situations it is most beneficial the company to manage the $\mathrm{OBC}$ or the consumers. Otherwise, Ahn et al. (2016) and Hankinson (2012) explore the relationship between the brand of certain locations (country, region) and brand orientation. Thus, some indications for future research are the study of other destinations, and taking into account the size of destinations (whether they are, for example, large or small cities in relation to population size or local development), the levels of brand resources and brand architecture.

Innovation seems to play a crucial role in performance, be it financial performance, brand performance or customer performance (Agostini and Nosella, 2016; Gisip and Harun, 2013; Lee et al., 2016; Wong and Merrilees, 2008). Lee et al. (2016) argue that an excessive focus on a single strategy (brand orientation or innovation orientation) may decrease returns of brand performance. The authors suggest to future researchers that this relation in the turbulent market, wherein the innovation orientation can be more important than brand orientation because of environmental characteristics. Another suggestion is to analyse performance from the customer's point of view (Lee et al., 2016).

Thus, another line for research is to explore the brand orientation of the internal and external perspectives. That is, from the points of view of managers and employees (internal perspective) and also taking into account the perceptions of consumers (external point of view), bringing a holistic view of the effects of brand orientation and possibly linking it with perceived brand orientation. Relating to higher education, perceived brand orientation is still little explored in distance learning (Casidy, 2014a; Shahijan et al., 2016).

\section{Conclusions}

In conclusion, this paper highlighted the relationships between the issues of brand orientation and discussed how the extensions of this concept have been applied. As the main theoretical contribution, the results of the cluster and the keyword groups showed the focus on the research in five areas: the development of the brand orientation concept and proposed extensions; hybrid strategies, mostly applied in SMEs and focusing in brand-market orientation; the relations between brand orientation, internal branding and brand management; the relation between brand orientation and brand or financial performance; the perceived brand orientation as mostly applied to higher education sector. In addition, despite the continued development of the brand orientation theme, many industries and segments still require investigation.

Also, although recent research is diversifying the countries studied (Ahn et al, 2016; Schmidt et al., 2017; Shahijan et al., 2016; Varadarajan and Malone, 2018; Zhang et al., 2016), taking into account the diversification between countries at different economic stages is necessary in an attempt to generalize the proposed models. In addition, given the complexity of adopting this type of strategy, more research can be done to clarify the background, consequents and barriers of brand orientation, their extensions and hybrid strategies, which are mainly useful managerial practices. Also, it would be interesting to perform a meta-analysis to further explore the details about the research questions related to brand orientation.

\section{References}

Agostini, L. and Nosella, A. (2016), "The Central role of a company's technological reputation in enhancing customer performance in the B2B context of SMEs", Journal of Engineering and Technology Management, Vol. 42, pp. 1-14. 
Ahn, Y.J., Hyun, S.S. and Kim, I. (2016), “City residents' perception of MICE city brand orientation and their brand citizenship behavior: a case study of Busan, South Korea", Asia Pacific Journal of Tourism Research, Vol. 21 No. 3, pp. 328-353.

Anees-Ur-Rehman, M., Wong, H.Y. and Hossain, M. (2016), "The progression of brand orientation literature in twenty years: a systematic literature review", Journal of Brand Management, Vol. 23 No. 6, pp. 612-630.

Anees-Ur-Rehman, M., Wong, H.Y., Sultan, P. and Merrilees, B. (2018), "How brand-oriented strategy affects the financial performance of B2B SMEs", Journal of Business and Industrial Marketing, Vol. 33 No. 3, pp. 303-315.

Anees-Ur-Rehman, M., Saraniemi, S., Ulkuniemi, P. and Hurmelinna-Laukkanen, P. (2017), "The strategic hybrid orientation and brand performance of B2B SMEs", Journal of Small Business and Enterprise Development, Vol. 24 No. 3, pp. 585-606.

Apaydin, F. (2011), "A proposed model of antecedents and outcomes of brand orientation for nonprofit sector”, Asian Social Science, Vol. 7 No. 9, pp. 194-202.

Balmer, J.M.T. (2013), "Corporate brand orientation: what is it? What of it?", Journal of Brand Management, Vol. 20 No. 9, pp. 723-741.

Baumgarth, C. (2010), "Living the brand": brand orientation in the business-to-business sector", European Journal of Marketing, Vol. 44 No. 5, pp. 653-671.

Baumgarth, C. and Schmidt, M. (2010), "How strong is the business-to-business brand in the workforce? An empirically-tested model of 'internal brand equity' in a business-to-business setting", Industrial Marketing Management, Vol. 39 No. 8, pp. 1250-1260.

Baxter, J., Kerr, G. and Clarke, R.J. (2013), “Brand orientation and the voices from within”, Journal of Marketing Management, Vol. 29 Nos 9/10, pp. 1079-1098.

Biedenbach, G. and Manzhynski, S. (2016), "Internal branding and sustainability: investigating perceptions of employees", Journal of Product and Brand Management, Vol. 25 No. 3, pp. 296-306.

Börner, K., Chen, C. and Boyack, K.W. (2003), "Visualizing knowledge domains", Annual Review of Information Science and Technology, Vol. 37 No. 1, pp. 179-255.

Boso, N., Carter, P.S. and Annan, J. (2016), "When is brand orientation a useful strategic posture?", Journal of Brand Management, Vol. 23 No. 4, pp. 363-382.

Brïdson, K. and Evans, J. (2004), "The secret to a fashion advantage is brand orientation”, International Journal of Retail and Distribution Management, Vol. 32 No. 8, pp. 403-411.

Brïdson, K., Evans, J., Mavondo, F. and Minkiewicz, J. (2013), "Retail brand orientation, positional advantage and organisational performance", The International Review of Retail, Distribution and Consumer Research, Vol. 23 No. 3, pp. 245-264.

Callon, M., Courtial, J.P., Turner, W.A. and Bauin, S. (1983), "From translations to problematic networks: an introduction to co-word analysis", Social Science Information), Vol. 22 No. 2, pp. 191-235.

Cant, M.C., Wiid, J.A. and Hung, Y.T. (2013), "The importance of branding for South African SMES: an exploratory study", Corporate Ownership and Control, Vol. 11 No. 1, pp. 735-744.

Casidy, R. (2013), "The role of brand orientation in the higher education sector: a student-perceived paradigm", Asia Pacific Journal of Marketing and Logistics, Vol. 25 No. 5, pp. 803-820.

Casidy, R. (2014a), "Brand orientation and service quality in online and offline environments: empirical examination in higher education”, Services Marketing Quarterly, Vol. 35 No. 3, pp. 236-254.

Casidy, R. (2014b), "Linking brand orientation with service quality, satisfaction, and positive word-ofmouth: evidence from the higher education sector", Journal of Nonprofit and Public Sector Marketing, Vol. 26 No. 2, pp. 142-161.

Chovancová, M., Osakwe, C.N. and Ogbonna, B.U. (2015), "Building strong customer relationships through brand orientation in small service firms: an empirical investigation", Croatian Economic Survey, Vol. 17 No. 1, pp. 111-138. 

impact of capabilities and brand orientation on SMBs performance", Journal of Business Economics and Management, Vol. 17 No. 6, pp. 1270-1285.

Ciunova-Shuleska, A., Palamidovska-Sterjadovska, N., Osakwe, C.N. and Omotoso, J. (2017), “The impact of customer retention orientation and brand orientation on customer loyalty and financial performance in SMEs: empirical evidence from a Balkan country", Journal of East European Management Studies, Vol. 22 No. 1, pp. 83-104.

Cobo, M.J., López-Herrera, A.G., Herrera-Viedma, E. and Herrera, F. (2011), "Science mapping software tools: review, analysis, and cooperative study among tools", Journal of the American Society for Information Science and Technology, Vol. 62 No. 7, pp. 1382-1402.

Dechawatanapaisal, D. (2018), "Employee retention: the effects of internal branding and brand attitudes in sales organizations", Personnel Review, Vol. 47 No. 3, pp. 675-693.

Downer, L. (2016), "It's the equity stupid! protecting the value of the partisan brand", Journal of Nonprofit and Public Sector Marketing, Vol. 28 No. 1, pp. 22-39.

Egghe, L. and Rousseau, R. (2002), "Co-citation, bibliographic coupling and a characterization of lattice citation networks", Scientometrics, Vol. 55 No. 3, pp. 349-361.

Elsevier (2019), "Content policy and selection”, [online], Elsevier, available at: www.elsevier.com/solutions/ scopus/how-scopus-works/content/content-policy-and-selection (accessed 22 October 2019).

Ewing, M.T. and Napoli, J. (2005), "Developing and validating a multidimensional nonprofit brand orientation scale", Journal of Business Research, Vol. 58 No. 6, pp. 841-853.

Fischer, M., Völckner, F. and Sattler, H. (2010), "How important are brands? A cross-category, crosscountry study", Journal of Marketing Research, Vol. 47 No. 5, pp. 823-839.

García, J.A.C., Galindo, A.D.V. and Suárez, R.M. (2018), "The effect of online and offline experiential marketing on brand equity in the hotel sector", Spanish Journal of Marketing-ESIC, Vol. 22 No. 1, pp. 22-41.

Gisip, I.A. and Harun, A. (2013), "Antecedents and outcomes of brand management from the perspective of resource based view (RBV) theory”, Mediterranean Journal of Social Sciences, Vol. 4 No. 10, pp. 432-438.

Gromark, J. and Melin, F. (2011), "The underlying dimensions of brand orientation and its impact on financial performance", Journal of Brand Management, Vol. 18 No. 6, pp. 394-410.

Gromark, J. and Melin, F. (2013), "From market orientation to brand orientation in the public sector", Journal of Marketing Management, Vol. 29 Nos 9/10, pp. 1099-1123.

Hankinson, G. (2012), "The measurement of brand orientation, its performance impact, and the role of leadership in the context of destination branding: an exploratory study", Journal of Marketing Management, Vol. 28 Nos 7/8, pp. 974-999.

Harrison-Walker, L.J. (2014a), "Manifestations of a strategic brand orientation”, Academy of Marketing Studies Journal, Vol. 18 No. 1, pp. 203-216.

Harrison-Walker, L.J. (2014b), "Strategic brand orientation and its antecedents", Academy of Marketing Studies Journal, Vol. 18 No. 2, pp. 49-65.

Hirvonen, S. and Laukkanen, T. (2014), "Brand orientation in small firms: an empirical test of the impact on brand performance", Journal of Strategic Marketing, Vol. 22 No. 1, pp. 41-58.

Hirvonen, S., Laukkanen, T. and Reijonen, H. (2013), "The brand orientation-performance relationship: an examination of moderation effects", Journal of Brand Management, Vol. 20 No. 8, pp. 623-641.

Hirvonen, S., Laukkanen, T. and Salo, J. (2016), "Does brand orientation help B2B SMEs in gaining business growth?", Journal of Business and Industrial Marketing, Vol. 31 No. 4, pp. 472-487.

Huang, Y.T. and Tsai, Y.T. (2013), "Antecedents and consequences of brand-oriented companies", European Journal of Marketing, Vol. 47 Nos 11/12, pp. 2020-2041. 
Iyer, P., Davari, A. and Paswan, A. (2018), "Determinants of brand performance: the role of internal branding", Journal of Brand Management, Vol. 25 No. 3, pp. 202-216.

Jain, V., Chawla, M., Ganesh, B.E. and Pich, C. (2018), "Exploring and consolidating the brand personality elements of the political leader", Spanish Journal of Marketing - ESIC, Vol. 22 No. 3, pp. 295-318.

Jarneving, B. (2005), “A comparison of two bibliometric methods for mapping of the research front", Scientometrics, Vol. 65 No. 2, pp. 245-263.

Kessler, M.M. (1963), "Bibliographic coupling between scientific papers”, American Documentation, Vol. 14 No. 1, pp. 10-25.

King, C. and So, K.K.F. (2015), "Enhancing hotel employees' brand understanding and brand-building behavior in China", Journal of Hospitality and Tourism Research, Vol. 39 No. 4, pp. 492-516.

King, C., So, K.K.F. and Grace, D. (2013), "The influence of service brand orientation on hotel employees' attitude and behaviors in China”, International Journal of Hospitality Management, Vol. 34, pp. 172-180.

Laukkanen, T., Tuominen, S., Reijonen, H. and Hirvonen, S. (2016), "Does market orientation pay off without brand orientation? a study of small business entrepreneurs", Journal of Marketing Management, Vol. 32 Nos 7/8, pp. 673-694.

Laukkanen, T., Nagy, G., Hirvonen, S., Reijonen, H. and Pasanen, M. (2013), "The effect of strategic orientations on business performance in SMEs: a multigroup analysis comparing Hungary and Finland”, International Marketing Review, Vol. 30 No. 6, pp. 510-535.

Lee, W.J., O'Cass, A. and Sok, P. (2016), "Why doesn't our branding pay off: optimising the effects of branding through innovation”, European Journal of Marketing, Vol. 50 Nos 3/4, pp. 509-529.

Lee, W.J., O'Cass, A. and Sok, P. (2017), "Unpacking brand management superiority: examining the interplay of brand management capability, brand orientation and formalization", European Journal of Marketing, Vol. 51 No. 1, pp. 177-199.

Li, H., An, H., Wang, Y., Huang, J. and Gao, X. (2016), "Evolutionary features of academic articles co-keyword network and keywords co-occurrence network: based on two-mode affiliation network", Physica A: Statistical Mechanics and Its Applications, Vol. 450, pp. 657-669.

Liu, G., Chapleo, C., Ko, W.W. and Ngugi, I.K. (2015), "The role of internal branding in nonprofit brand management: an empirical investigation", Nonprofit and Voluntary Sector Quarterly, Vol. 44 No. 2, pp. 319-339.

Liu, G., Ko, W.W. and Chapleo, C. (2017), "Managing employee attention and internal branding", Journal of Business Research, Vol. 79, pp. 1-11.

Losiewicz, P., Oard, D.W. and Kostoff, R.N. (2000), "Textual data mining to support science and technology management”, Journal of Intelligent Information Systems, Vol. 15 No. 2, pp. 99-119.

M'zungu, S.D., Merrilees, B. and Miller, D. (2017), "Strategic hybrid orientation between market orientation and brand orientation: guiding principles", Journal of Strategic Marketing, Vol. 25 No. 4, pp. 275-288.

Marchiori, D. and Mendes, L. (2018), "Knowledge management and total quality management: foundations, intellectual structures, insights regarding evolution of the literature”, Total Quality Management and Business Excellence, pp. 1-35.

Mulyanegara, R.C. (2011a), "The relationship between market orientation, brand orientation and perceived benefits in the non-profit sector: a customer-perceived paradigm", Journal of Strategic Marketing, Vol. 19 No. 5, pp. 429-441.

Mulyanegara, R.C. (2011b), "The role of brand orientation in church participation: an empirical examination", Journal of Nonprofit and Public Sector Marketing, Vol. 23 No. 3, pp. 226-247.

Napoli, J. (2006), "The impact of nonprofit brand orientation on organisational performance", Journal of Marketing Management, Vol. 22 Nos 7/8, pp. 673-694. 
O'Cass, A. and Voola, R. (2011), "Explications of political market orientation and political brand orientation using the resource-based view of the political party", Journal of Marketing Management, Vol. 27 Nos 5/6, pp. 627-645.

Osakwe, C.N., Boateng, H., Popa, S., Chovancová, M. and Soto-Acosta, P. (2016), "Understanding cosmopolitan consumers' repeat purchasing in the eMarketplace: contribution from a brand orientation theoretical perspective", E+M Ekonomie a Management, Vol. 19 No. 4, pp. 149-166.

Perianes-Rodriguez, A., Waltman, L. and Van Eck, N.J. (2016), "Constructing bibliometric networks: a comparison between full and fractional counting", Journal of Informetrics, Vol. 10 No. 4, pp. 1178-1195.

Powell, S.M. (2016), "Journal of brand management-year end review 2016", Journal of Brand Management, Vol. 23 No. 6, pp. 601-611.

Pritchard, A. (1969), "Statistical bibliography or bibliometrics", Journal of Documentation, Vol. 25 No. 4, pp. 348-349.

Reid, M., Luxton, S. and Mavondo, F. (2005), "The relationship between integrated marketing communication, market orientation, and brand orientation", Journal of Advertising, Vol. 34 No. 4, pp. 11-23.

Reijonen, H., Laukkanen, T., Komppula, R. and Tuominen, S. (2012), “Are growing SMEs more marketoriented and brand-oriented?”, Journal of Small Business Management, Vol. 50 No. 4, pp. 699-716.

Reijonen, H., Hirvonen, S., Nagy, G., Laukkanen, T. and Gabrielsson, M. (2015), "The impact of entrepreneurial orientation on B2B branding and business growth in emerging markets", Industrial Marketing Management, Vol. 51, pp. 35-46.

Reijonen, H., Párdányi, S., Tuominen, S., Laukkanen, T. and Komppula, R. (2014), “Are growth-oriented SMEs more likely to adopt market and brand orientations?", Journal of Small Business and Enterprise Development, Vol. 21 No. 2, pp. 250-264.

Rentschler, R., Brïdson, K. and Evans, J. (2011), "Portrait of a star: national gallery of Victoria", International Journal of Arts Management, Vol. 13 No. 2, pp. 59-73.

Santos-Vijande, M.L., del Río-Lanza, A.B., Suárez-Álvarez, L. and Díaz-Martín, A.M. (2013), “The brand management system and service firm competitiveness", Journal of Business Research, Vol. 66 No. 2, pp. 148-157.

Schmidt, H.J., Mason, R., Steenkamp, P. and Mugobo, V. (2017), "Does brand orientation contribute to retailers' success? An empirical study in the South African market”, Journal of Retailing and Consumer Services, Vol. 38, pp. 210-222.

Shahijan, M.K., Rezaei, S. and Amin, M. (2016), "International students' course satisfaction and continuance behavioral intention in higher education setting: an empirical assessment in Malaysia", Asia Pacific Education Review, Vol. 17 No. 1, pp. 41-62.

Simões, C. and Dibb, S. (2001), "Rethinking the brand concept: new brand orientation", Corporate Communications: An International Journal, Vol. 6 No. 4, pp. 217-224.

Simon, C.J. and Sullivan, M.W. (1993), "The measurement and determinants of brand equity: a financial approach", Marketing Science, Vol. 12 No. 1, pp. 28-52.

Sinkovics, N. (2016), "Enhancing the foundations for theorising through bibliometric mapping", International Marketing Review, Vol. 33 No. 3, pp. 327-350.

Terglav, K., Ruzzier, M.K. and Kaše, R. (2016), "Internal branding process: exploring the role of mediators in top management's leadership-commitment relationship”, International Journal of Hospitality Management, Vol. 54, pp. 1-11.

Urde, M. (1994), "Brand orientation - a strategy for survival", Journal of Consumer Marketing, Vol. 11 No. 3, pp. 18-32.

Urde, M. (1999), "Brand orientation: a mindset for building brands into strategic resources", Journal of Marketing Management, Vol. 15 Nos 1/3, pp. 117-133. 
Urde, M. and Koch, C. (2014), "Market and brand-oriented schools of positioning", Journal of Product and Brand Management, Vol. 23 No. 7, pp. 478-490.

Urde, M., Baumgarth, C. and Merrilees, B. (2013), "Brand orientation and market orientation-from alternatives to synergy", Journal of Business Research, Vol. 66 No. 1, pp. 13-20.

Van Eck, N. and Waltman, L. (2010), "Software survey: VOSviewer, a computer program for bibliometric mapping”, Scientometrics, Vol. 84 No. 2, pp. 523-538.

Van Eck, N.J. and Waltman, L. (2014), "Visualizing bibliometric networks", in Ding, Y., Rousseau, R., Wolfram, D. (Eds), Measuring Scholarly Impact, Springer, Cham, pp. 285-320.

Van Eck, N. and Waltman, L. (2019), VOSviewer Manual: Manual for VOSviewer Version 1.6.10, Universiteit Leiden, Leiden.

Varadarajan, B. and Malone, T. (2018), "Branding strategies of a private international school", The Qualitative Report, Vol. 23 No. 4, pp. 932-948.

Wallace, E., Buil, I. and de Chernatony, L. (2013), "Brand orientation and brand values in retail banking”, Journal of Marketing Management, Vol. 29 Nos 9/10, pp. 1007-1029.

Waltman, L., Van Eck, N.J. and Noyons, E.C. (2010), "A unified approach to mapping and clustering of bibliometric networks", Journal of Informetrics, Vol. 4 No. 4, pp. 629-635.

Wang, Q. and Waltman, L. (2016), "Large-scale analysis of the accuracy of the journal classification systems of web of science and scopus", Journal of Informetrics, Vol. 10 No. 2, pp. 347-364.

Wirtz, J., Den Ambtman, A., Bloemer, J., Horváth, C., Ramaseshan, B., Van De Klundert, J., Canli, Z.G. and Kandampully, J. (2013), "Managing brands and customer engagement in online brand communities", Journal of Service Management, Vol. 24 No. 3, pp. 223-244.

Wong, H.Y. and Merrilees, B. (2005), "A brand orientation typology for SMEs: a case research approach", Journal of Product and Brand Management, Vol. 14 No. 3, pp. 155-162.

Wong, H.Y. and Merrilees, B. (2007a), "Closing the marketing strategy to performance gap: the role of brand orientation", Journal of Strategic Marketing, Vol. 15 No. 5, pp. 387-402.

Wong, H.Y. and Merrilees, B. (2007b), "Multiple roles for branding in international marketing", International Marketing Review, Vol. 24 No. 4, pp. 384-408.

Wong, H.Y. and Merrilees, B. (2008), "The performance benefits of being brand-orientated", Journal of Product and Brand Management, Vol. 17 No. 6, pp. 372-383.

Wong, H.Y. and Merrilees, B. (2015), "An empirical study of the antecedents and consequences of brand engagement”, Marketing Intelligence and Planning, Vol. 33 No. 4, pp. 575-591.

Zhang, J., Jiang, Y., Shabbir, R. and Zhu, M. (2016), "How brand orientation impacts B2B service brand equity? An empirical study among Chinese firms", Journal of Business and Industrial Marketing, Vol. 31 No. 1, pp. 83-98.

\section{Further reading}

Veljković, S. and Kaličanin, D. (2016), "Improving business performance through brand management practice”, Economic Annals, Vol. 61 No. 208, pp. 137-167.

\section{Corresponding author}

Emerson Wagner Mainardes can be contacted at: emerson@fucape.br

For instructions on how to order reprints of this article, please visit our website:

www.emeraldgrouppublishing.com/licensing/reprints.htm

Or contact us for further details: permissions@emeraldinsight.com 